\title{
Subjective Lowering of Preprandial Blood Glucose and Cancer Prevention by Planning and Recognizing Initial Hunger
}

\author{
Mario Ciampolini \\ Retired, Preventive Gastroenterology Unit, Department of Paediatrics, Università di Firenze, Firenze, Italy \\ Email: mlciampolini@fastwebnetit
}

How to cite this paper: Ciampolini, M. (2019) Subjective Lowering of Preprandial Blood Glucose and Cancer Prevention by Planning and Recognizing Initial Hunger. Open Journal of Preventive Medicine, 9, $1-10$.

https://doi.org/10.4236/ojpm.2019.91001

Received: December 3, 2018

Accepted: January 28, 2019

Published: January 31, 2019

Copyright $\odot 2019$ by author(s) and Scientific Research Publishing Inc. This work is licensed under the Creative Commons Attribution International License (CC BY 4.0).

http://creativecommons.org/licenses/by/4.0/

(c) (i) Open Access

\begin{abstract}
We recently described the training of the passage from scheduled to demanded meals in infants and adults. Subjects reduced energy intake by subjectively abolishing conditioned meals and by allowing intake only after demand by the infant or after hunger perception by the adult (Initial Hunger Meal Pattern; IHMP). Conditioned meals were those scheduled and/or presented to the infant as well to the adult by sight, smell, mentioning, gesturing or simply at a fixed mealtime. During IHMP instead, meals were suspended until the first infant's demand or until an adult's self-noticing arousal of hunger. IHMP was checked by measuring blood glucose before three meals per day (MBG) and was associated with significant decreases in diary-reported energy-intake, MBG, glycated hemoglobin, body weight, insulin AUC in glucose tolerance tests and in days with diarrhea as compared to randomized control subjects who maintained conditioned meals. Although generalized, conditioned eating is a modern aberration that is associated with development of insulin resistance and overall inflammation. These associations are well demonstrated independently from the implicated mechanism. A state of Overall Subclinical Inflammation greatly increases cell and DNA replications and replication errors. After decades of DNA errors, oncogenic cells arise and cumulate. A prevention of malignancies is possible by interrupting the development of conditioned eating, insulin resistance and associated overall inflammation.
\end{abstract}

\section{Keywords}

Blood Glucose, Diabetes, Insulin Resistance, Overweight, Fattening, Energy Balance, Energy Intake, Limit in Energy Intake, Hunger, Meal Onset, Energy Availability, Malignant Diseases, Bowel Disorders, Malnutrition, Cancer 


\section{Introduction}

In past studies, energy availability and Mean Blood Glucose (MBG) were maintained at different levels within the (sedentary) normal in time variability between $65 \mathrm{mg} / \mathrm{dL}$ and $110 \mathrm{mg} / \mathrm{dL}$ before meals and before any training on energy intake [1] [2]. After bearable meal suspension and recognition of ensuing hunger (Initial Hunger, IH) before all meals, the MBG decreased from $91.6 \pm 7.7 \mathrm{mg} / \mathrm{dL}$ before training to $76.6 \pm 3.7 \mathrm{mg} / \mathrm{dL}$ BG after training [1] [2]. This MBG decrease was associated with decrease of insulin resistance and HBalc [1] [2]. In absence of any training, high BG and insulin resistance persist for years and decades in association with overall inflammation. A high number of immune and tissue cells dye and are substituted by replication, with few errors in DNA replication. After years and decades some oncogenic cells develop among the cells with DNA errors [3] [4] [5] [6]. Only a consistent minority (30\% - 35\%) of population maintains insulin resistance, high MBG and overall inflammation on one hand and cancer development on the other [1]-[6]. Prevention was thus uneasy as it was eating limitation of $33 \%$ energy intake. Up to now, no definite target in the intake decrease amount had large consensus. After training, recognition of initial hunger and prediction of current BG are easy in young people before 60. After this learning, people decrease energy intake by a mean $30 \%$ (of recruitment value). Table 1 and Table 2 report the metabolic conditions before and after training in various human groups. The metabolic condition before training is typical of overall inflammation and cancer development. The metabolic condition after training corresponds to that of cancer prevention in animal studies [3] [4] [5] [6].

The amount of immune cells in the intestinal mucosa is impressive [7] [8] [9] [10] [11]. Mowat, Brandtzaeg and Abrams calculated that more than half immune cells in the body were developing in the intestinal mucosa. This huge immune defense is active against intestinal microflora [9] [10] [11] [12]. About

Table 1. Initial hunger meal pattern, effects on energy metabolism.

\begin{tabular}{|c|c|c|c|c|}
\hline training & BEFORE & AFTER & BEFORE & AFTER \\
\hline & \multicolumn{2}{|c|}{ Energy intake } & \multicolumn{2}{|c|}{ M B G } \\
\hline $38 \mathrm{OW}$ adults & $1756 \pm 585$ & $1069 \pm 487$ & $86.8 \pm 8.7$ & $78.8 \pm 6.8$ \\
\hline $40 \mathrm{NW}$ adults & $1852 \pm 697$ & $1270 \pm 457$ & $91.4 \pm 7.7$ & $80.1 \pm 6.6$ \\
\hline 70 Toddlers & $946 \pm 230$ & $749 \pm 187$ & $86.9 \pm 9.4$ & $76.4 \pm 6.7$ \\
\hline \multicolumn{5}{|c|}{ R M R } \\
\hline 14 Toddlers & $58.6 \pm 7.8$ & $49.0 \pm 9.1$ & & \\
\hline
\end{tabular}

Note: Assessments before and after 5 months training. All pre-post and longitudinal differences (from controls) are significant. (Elaborated from references 1 and 2). RMR = resting metabolic rate in $\mathrm{Kcal} / \mathrm{Kg}$ body weight. $\mathrm{MBG}=$ Mean of 21 home measurements in $\mathrm{mg} / \mathrm{dL}$ during a week reported by diary. Courtesy of Ciampolini 2018, copyright owner under the terms of the Creative Commons Attribution License <http://creativecommons.org/licenses/by/2.0 $>$. 
Table 2. Initial hunger meal pattern and effects on insulin curve and BMI.

\begin{tabular}{ccccc}
\hline & \multicolumn{2}{c}{26 trained OW } & \multicolumn{2}{c}{13 control OW } \\
\hline Either before or after 5 months & Before & after & before & after \\
\hline OW adults with High MBG BMI & $29.0 \pm 4.1$ & $26.5 \pm 4.0$ & $29.2 \pm 3.9$ & $27.8 \pm 4.2$ \\
& \multicolumn{2}{c}{40 NW } & 15 control NW \\
NW adults with High MBG BMI & $21.8 \pm 2.4$ & $20.7 \pm 1.9$ & $20.2 \pm 2.3$ & $21.4 \pm 2.1$ \\
(High MBG) & 55 High MBG & 19 High MBG control \\
Insulin area under curve at GTT & $244 \pm 138$ & $164 \pm 92$ & $222 \pm 81$ & $214 \pm 98$ \\
(Low MBG) & 34 trained & & 12 control \\
Insulin area under curve at GTT & $180 \pm 98$ & $183 \pm 83$ & $192 \pm 106$ & $243 \pm 133$ \\
\hline
\end{tabular}

Note: Assessments before and after 5 months after training. IHMP and MBG were the most significant predictors of BMI in multivariate analysis of variance. High MBG OW subjects are here reported. (Data from reference 1, 2). MBG = Mean of 21 measurements during a week. High MBG $=$ MBG $>81.8 \mathrm{mg} / \mathrm{dL}$ Low MBG $=$ MBG $<81.8 \mathrm{mg} / \mathrm{dL}$. BMI $=$ Body Mass Index. GTT $=$ Glucose Tolerance Test, Insulin area under curve at GTT. All pre-post and longitudinal differences (from controls) are significant, except for the bottom line where only longitudinal difference is significant. Courtesy of Ciampolini 2018, copyright owner under the terms of the Creative Commons Attribution License $<$ http://creativecommons.org/licenses/by/2.0 $>$.

thousand bacteria species grow in the intestine [12]. Most bacteria species do not provoke a known illness like salmonella or cholera. More than half do not interact at all with mucosa [12]. Less than half number of immune cells in the mucosa put $10^{17} \mathrm{IgA}$ molecules into intestine every day [12]. These molecules do not kill bacteria, the IgA molecules only obstacle mucosa invasion by bacteria. Ten to hundred species from thousand in intestine stimulate an immune reaction. There are low responses by IgM and IgG and these are capable of inducing inflammation. Inflammations are spot like and localized in some segments and absent in others [13] [14]. These bacteria stimulate production of IgG and IgM and inflammations. [12] [13]. In vitro [13] [14], bacteria were capable of destruction on epithelial cells of intestinal mucosa. Bacteria grow in the small and large intestine in dependence on nutrients, mainly on those nutrients that produce energy availability (sugars, carbohydrates, amino-acids, fats) [7] [8] [9] [10] [11]. Long persistence of nutrients in the bowel is frequent. Absorption and progression of nutrients slow down during BG increases. Changes in climate or in home heating and in physical activity change also energy expenditure [15] [16] [17]. High environmental temperature spares energy. Resting Metabolic Rate in mammals largely (90\%) covers body maintenance at $37^{\circ}$. Thus intake and intestinal absorption diminish in a warm environment [15] [16] [17]. Maintenance of the same intake promotes delay in absorption and an elevation of energy availability. This energy availability extends from blood to tissues and also into intestine that diminishes absorption. Nitrogen and carbohydrates are used by bacteria to grow. The increase of bacteria number and mucosal stimulation provokes relapses of functional disorders, diarrhea in children. During diarrhea relapses in children we actually found high blood glucose (BG) [1] [2] 
[18] [19] [20]. These functional events prevail more and more in the evolution from insulin resistance to diabetes. The conflict consists in the competition for absorption and in inflammation that kills immune and tissue cells and leaves destructions. Humans are interested to stop the evolution to diabetes as well as events of eating when BG is high. In the purpose of diminishing immune reactions, humans may eat in order to have a new event of hunger after a planned number of hours. The application of this anti-conflictual strategy in subjects with relapsing disorders stopped the disorders better than the application of other clinical interpretations [1] [2] [19]. A subject must learn the correspondence of hunger and body sensations with BG measurements [18]. After this learning, the subject ought to learn the amount of energy that is necessary to prevent IH arousal in the subsequent hours: e.g., for 4 or 6 hours. In this calculation, the subject must be aware of differences in expenditure for changes of climate, activity etc. A longer interval from the meal produced a greater decrease in bacteria number [11] [21]. This association was exploited in chronic diarrhea [2] [19] [20] [22], during repeated vomiting and malnutrition [23] as well as for nutrition in healthy times [21]. The meal absorption develops in a competition between mucosa cells and bacteria proliferation [11] [21]. Local increase in immunogenic bacteria produces a conflictual inflammation [3] [22]. The progressive increase in adipose tissue subtracts energy (BG) from general availability. This is a way to slow and delay the development of diabetes. An increase in monocytes shows the participation of adipose tissue to overall inflammation.

The "overall inflammation" implies increase in turnover, increase in cell deaths and cell renewal, increase in DNA replication and in DNA errors, increase in oncogenic DNA and oncogenic cells, increase in malignant development in the inflamed tissues, e.g., joints, vascular walls, bronchial and colonic mucosa, etc.. Suppression of the general habit to conditioned intake is associated with $30 \%$ decrease in energy intake. The same 30\% decrease in energy intake largely decreases tumor arousal in experimental animals [1] [2] [3]. In the last 50 years, Mauron missed ahomeostatic method for energy intake to contrast malignancies [3]. The novelty now consists in changing meal pattern to introduce an energy intake that reveals to be homeostatic [1] [2]. The novel habit calculates the energy intake at each meal that allows initial hunger arousal three times a day (4 to 2 depending on age) [1] [2]. This meal pattern is associated with the same energy intake decrease from conditioned intake (a mean-30\%) that prevents overall inflammation in humans as well as malignancy in animals (1 - 3). This novel meal pattern is homeostatic, i.e., at each meal provides the least excess over expenditure and the least bacterial growth in intestine. The homeostatic provision maintains the safest balance among intestinal bacteria species and the least development of overall inflammation in the body [1] [2] [3]. Overall inflammation increases cell death, cell and DNA replications and it increases oncogenic errors in localized sites as well as in all body. After decades of conditioned meal pattern, the prevalence of oncogenic aberrations becomes significant 
[3]-[11]. Future physicians still need to remake the here reported scientific steps. The need for further confirmatory search for the development of malignancy shall never stop. Why a decrease in energy intake has not been already taken? Is it too simplistic for a huge problem like tumors? Are humans resigned to pay in tumor development a fatal toll for being human? Are humans prepared to a fatal assistential organization that we can only improve in its working but cannot eliminate to implement a poorly known radical solution?

The current novelty in this question consists in the possibility for anyone to implement Initial Hunger by self help. This subjective implementation cannot be reached by a fixed energy intake. A lower mean energy intake may be easily reached but does not allow a reasonably narrow BGSD in the face of a daily variability in energy expenditure [1] [2] [9] [10] [11] [12] [13]. No consideration of the importance of this SD stability invalidates the lower MBG. Objective limits in energy intake (1000 to $2000 \mathrm{kcal}$ per day) produce an inconstant lowering that alone may suffice for attenuating vascular risks. Actually, IH recognition more times per day is associated with a significantly decreased SD of (of energy availability) and of MBG as compared to conditioned intake [1] [2] [19]. Awareness on BG may be acquired by a personal training even without medical support except for encouraging. The spreading of this information has begun in Boston [24].

\section{Conclusions}

A minority of the Western (and Tuscan) population prevents already overall inflammation and malignancies. Another part already asserts "would I have known earlier". The consistency of these minorities suggests that conditioned intake is chosen haphazard, by absurd casualty as it was observed in novel mothers at birth [25]. Thus, the first intervention consists in orienting nutrition and energy balance against the development of overall inflammation, i.e. targeting insulin sensitivity or decreasing insulin resistance in meal pattern. This objective is anyway useful to depress vascular risks and diabetes development [1] [2].

Eating is a biophysical event that is decided subjectively in the start, in energy amount and density, in the items and in the end. The subjective participation is unavoidable. Dieticians may suggest eating $1000 \mathrm{kcal}$ per day and this suggestion constructs an eating without subjectivity until the patient mechanically endures this rigid pattern. Days with an increase in energy expenditure impose again subjectivity and a subjective increase in energy intake. Given the pervasive nature of subjectivity during meals, also a subjective method must be considered as appropriate and rigorously scientific: Three (four or two, depending on age) events of Initial Hunger per day mark the best adaptation of energy intake to homeostatic energy and BG availability in blood, least bacteria growth in the intestine, least overall inflammation and least cell replications in the body. The subjectivity of the described method provided the adaptability of energy intake decrease that Mauron missed in the last 50 years of attempts to contrast malignancies [1] [2]. 


\section{Acknowledgements}

The Author acknowledges the indispensable collaboration in writing with Stella Zagaria, David Lowell-Smith (NZ) and Riccardo Bianchi (NY), and the strategic, statistical support by Cutberto Garza (Rector, Boston College), Giuliano Parrini (Professor of Physics, Firenze) and Andrea Giommi (Professor of Statistics, Firenze). The here summarized researches were supported by the Italian Ministry of University, Research, Science and Technology grants for the years 1998-2002 and by ONLUS Nutrizione e Prevenzione, Firenze, for the years 2003-2018. This review has been shown in: "Modifying Eating Behavior: Novel Approaches for Reducing Body Weight, Preventing Weight Regain and Reducing Chronic Disease Risk” ASN’s Annual Meeting \& Scientific Sessions at Experimental Biology 2014, April 26-30.

\section{Conflicts of Interest}

The author declares no conflicts of interest regarding the publication of this paper.

\section{References}

[1] Ciampolini, M. (2018) Initial Hunger, a Subjective, Reproducible Limit in Intake Associated with Low Blood Glucose: A Training for Malnourished Infants and Overweight Adults. In: Predy, V. and Patel, V.B., Eds., Handbook of Famine, Starvation, and Nutrient Deprivation, Springer International Publishing AG, Part of Springer Nature, 1-18.

https://link.springer.com/referenceworkentry/10.1007/978-3-319-40007-5_125-1 https://doi.org/10.1007/978-3-319-40007-5_125-1

[2] Ciampolini, M. and Sifone, M. (2011) Differences in Maintenance of Mean Blood Glucose (BG) and Their Association with Response to "Recognizing Hunger". International Journal of General Medicine, 4, 403-412. https://doi.org/10.2147/IJGM.S19035

[3] Mauron, J., Anantharaman, K., Finot, P.A., Horisberger, M., Ingenbleeck, Y. and Wuerzner, H.P. (1982) Nutritional Adequacy, Nutrient Availability and Needs. Springer AG, Basel.

[4] Jayedi, A., Emadi, A. and Shab-Bidar, S. (2018) Dietary Inflammatory Index and Site-Specific Cancer Risk: A Systematic Review and Dose-Response Meta-Analysis. Advances in Nutrition, 9, 388-403. https://doi.org/10.1093/advances/nmy015

[5] Luzzatto, L. and Pandolfi, P.P. (2015) Causality and Chance in the Development of Cancer. New England Journal of Medicine, 373, 84-88. https://doi.org/10.1056/NEJMsb1502456

[6] Mooi, W.J. and Peeper, D.S. (2006) Oncogene-Induced Cell Senescence-Halting on the Road to Cancer. New England Journal of Medicine, 355, 1037-1046. https://doi.org/10.1056/NEJMra062285

[7] Mowat, A.M. (1987) The Cellular Basis of Gastrointestinal Immunity. In: Marsh, M.N., Ed., Immunopathology of the Small Intestine, John Wiley \& Sons, Chichester, 44.

[8] Abrams, G.D. (1977) Microbial Effects on Mucosal Structure and Function. American Journal of Clinical Nutrition, 30, 1980-1986. 
https://doi.org/10.1093/ajcn/30.11.1880

[9] Brandtzaeg, P., Halstensen, T.S., Kett, K., Krajci, P., Kvale, D., et al. (1989) Immunobiology and Immunopathology of Human Gut Mucosa: Humoral Immunity and Intraepithelial Lymphocytes. Gastroenterology, 97, 1562-1584. https://doi.org/10.1016/0016-5085(89)90406-X

[10] Hungate, R.E. (1967) Ruminal Fermentation. In: Heidel, W. and Code, C.F., Eds., Handbook of Physiology, Sect 6, Alimentary Canal, American Physiological Society, Washington DC, 2725.

[11] Ciampolini, M., Bini, S. and Orsi, A. (1996) Microflora Persistence on Duodeno-Jejunal Flat or Normal Mucosa in Time after a Meal in Children. Physiology \& Behavior, 60, 1551-1556. https://doi.org/10.1016/S0031-9384(96)00312-5

[12] Van der Waaij, L.A., Limburg, P.C., Mesander, G. and van der Waaij, D. (1996) In Vivo IgA Coating of Anaerobic Bacteria in Human Faeces. Gut, 38, 348-354. https://doi.org/10.1136/gut.38.3.348

[13] Ciampolini, M. and Marianelli, L. (1969) Azione dei germi nel tenue. Nota II: E. Coli nel ratto lattante. Studio microbiologico, istologico e biochimico. Riv Clin Ped., 82, 78-84.

[14] Ciampolini, M., Becciolini, P.A. and Marianelli, L. (1969) Azione dei germi nel tenue. Azione sulla saccarasi e leucinaminopeptidasi in Vitro. Riv Clin Ped., 82, 99-104.

[15] Ciampolini, M. (1974) Influence of Environmental Temperature on Intestinal Absorption Xylose in Rats in Vivo. IRCS, 2, 1545.

[16] Ciampolini, M. (1976) Influence of Environmental Temperature on Xilose Absorption in Man. IRCS Medical Science, 4, 208.

[17] Ciampolini, M. (1976) Influence of Environmental Temperature on Xylose Absorption Test in Children and Adults. 10th International Congress of Gastroenterology, Budapest, 23-29 June 1976.

[18] Ciampolini, M. and Bianchi, R. (2006) Training to Estimate Blood Glucose and to Form Associations with Initial Hunger. Nutrition \& Metabolism, 3, 42.

http://www.nutritionandmetabolism.com/content/3/1/42 https://doi.org/10.1186/1743-7075-3-42

[19] Ciampolini, M., Lovell-Smith, D. and Sifone, M. (2010) Sustained Self-Regulation of Energy Intake. Loss of Weight in Overweight Subjects. Maintenance of Weight in Normal-Weight Subjects. Nutrition \& Metabolism, 7, 1-4. http://www.nutritionandmetabolism.com/content/7/1/4 https://doi.org/10.1186/1743-7075-7-4

[20] Cooper, I.F. and Siadaty, M.S. (2014) "Bacteriums" Associated with "Blood Glucose Level Finding".

[21] Ciampolini, M., Borselli, L. and Giannellini, V. (2000) Attention to Metabolic Hunger and Its Effects on Helicobacter pylori Infection. Physiology \& Behavior, 70, 287-296. https://doi.org/10.1016/S0031-9384(00)00273-0

[22] Mccoy, K. and Köller, Y. (2015) New Developments Providing Mechanistic Insight into the Impact of the Microbiota on Allergic Disease. Clinical Immunology, 5, 007.

[23] Ciampolini, M. and Cecchi, G. (2017) Severe Malnutrition, Radiation Enteritis and Insulin Resistance: A Solution by Initial Hunger and Associated Low Blood Glucose. SciFed Journal of Diabetes and Endocrinology, 1, 1.

[24] HuaShen, D.K. and Goldstein, D.R. (2013) Processes of Sterile Inflammation. The 
Journal of Immunology, 191, 2857-2863.

[25] Ciampolini, M. (2012) Requested Meals versus Scheduled Meals. International Journal of General Medicine, 5, 345-353. https://doi.org/10.2147/IJGM.S29889

\section{List of Terms and Abbreviations}

BG = Blood Glucose, an index of energy availability in blood for the whole body. $\mathrm{IH}=$ Initial Hunger consists of gastric pangs or mind or physical weakness: Inedia is the Italian word for this weakness. In sedentary adults and in children, IH corresponds to $76.6 \pm 3.7 \mathrm{mg} / \mathrm{dL}$ BG. In infancy corresponds to demand before sight of food.

IHMP: Initial Hunger Meal Pattern: Energy intake is adjusted to three arousals of IH per day.

OGTT $=$ oral glucose tolerance test.

AUC $=$ area under curve of GTT

MBG = The mean of 21 BG measurements before the three main daily meals reported by a week diary. MBG measures the compliance with IHMP, MBG shows changes after training and it is negatively correlated to insulin sensitivity. Below $81.8 \mathrm{mg} / \mathrm{dL}$ (Low MBG) MBG indicates a healthy meal pattern in sedentary people. Over $81.8 \mathrm{mg} / \mathrm{dL}$, High MBG is associated with fattening/insulin resistance. 


\section{Summary Points}

- After training, a patient is able to assess Blood Glucose (BG) and make energy intake self-adjustments.

- Initial Hunger Meal Pattern (IHMP) reduces Fattening/insulin resistance and the associated overall sterile inflammation, for example IHMP stops diarrhea relapses.

- Time requirement for insulin resistance development as well as regression depends on fattening capabilities. It may persist only three days in children with arm skinfold thickness lower than $7 \mathrm{~mm}$.

- Undernourished, normal-weight and overweight people exit from insulin-resistance/fattening condition and develop insulin sensitivity by training IHMP.

- Undernourished infants and overweight adults equally improve their body weight under IHMP.

- A third of healthy people shows already at recruitment (before any training) the same MBG and the associated insulin sensitivity that are gained by compliant people after training. A MBG of $76.6 \pm 3.7 \mathrm{mg} / \mathrm{dL}$ was found in 31 out of 120 adults at recruitment who maintained stable body weight and insulin sensitivity during IHMP. We found consistent results in infants and other groups.

- Initial hunger arises between 0 and $48 \mathrm{~h}$ after meals in healthy children and healthy adults but not in obese diabetics.

- An initial hunger meal pattern (IHMP) consists of initial hunger arousal three times a day. In comparison with conditioned intake, practicing IHMP is associated with lower insulin resistance $(-30 \%)$, lower energy intake $(-18 \%)$, lower mean blood glucose (MBG) $(-15 \%$ to $-20 \%)$, lower resting metabolic rate (RMR) (-15\%), and lower total energy expenditure (TEE) $(-16 \%)$.

- The individual decrease toward an even energy balance under IHMP is proportionate to the value at recruitment.

- About a third of healthy people show at recruitment (before any training) the same low MBG, low RMR, and associated insulin sensitivity that are gained by people after training IHMP.

- These facts suggest together that initial hunger corresponds to a reproducible metabolic condition that can be identified and recognized by humans since the neonatal period.

- A meal pattern with an energy intake that allows initial hunger arousal three times a day (or 2 or 4 ) is associated with the same energy intake decrease (a mean $-30 \%)$ that prevents malignancy in animals $(1-3)$.

\section{Why}

In the last 50 years, Mauron missed a method of lowering intake that contrasted malignancies [1] [2] [3]. The novelty now consists in a meal pattern with an 
energy intake that is based on three initial hunger arousals per day [1] [2]. This meal pattern is associated with the same energy intake decrease from conditioned intake (a mean-30\%) that prevents malignancy in animals $(1-3)$. This meal pattern provides the least bacterial growth and maintains the best balance among intestinal bacteria species for the least development of overall inflammation [1] [2] [3]. Overall inflammation increases cell death, cell and DNA replications and increases oncogenic errors through decades. 